\title{
MicroRNA-106a inhibits cell proliferation and induces apoptosis in colorectal cancer cells
}

\author{
QINGHUA HUANG ${ }^{1}$ and QUNYING MA ${ }^{2}$ \\ ${ }^{1}$ Department of Breast Surgery, The Affiliated Tumor Hospital of Guangxi Medical University, \\ Nanning, Guangxi 530021; ${ }^{2}$ Department of Gastroenterology, The Fifth Affiliated Hospital \\ of Guangzhou Medical University, Guangzhou, Guangdong 510700, P.R. China
}

Received January 12, 2016; Accepted June 9, 2017

DOI: $10.3892 / \mathrm{ol} .2018 .8516$

\begin{abstract}
MicroRNAs (miRNAs) regulate mammalian cell growth, differentiation and apoptosis by altering the expression of other genes, and serve multiple roles in tumorigenesis and progression. miR-106a has been implicated in several types of malignancies. However, its role in colorectal cancer (CRC) remains unknown. The present study reported that in this particular cancer, miR-106a exhibits a tumor suppressive role. It was demonstrated that the high expression of miR-106a in CRC cells is negatively associated with E2F transcription factor 1 protein level and positively associated with caspase activation, suggesting a potential molecular switch.
\end{abstract}

\section{Introduction}

Each year, $>1$ million new cases of colorectal cancer (CRC) are diagnosed worldwide. CRC is the third most common malignancy and the fourth most common cause of cancer-associated mortality (1). Despite novel biological insights and advances in therapy, the prognosis of patients with CRC remains poor. The molecular mechanisms underlying malignant tumor occurrence and progression was investigated, with the aim of developing more effective therapies against CRC.

MicroRNAs (miRNAs) are a group of endogenous small noncoding RNAs that are 21-25 nucleotides in size. The primary function of miRNA is to suppress gene expression, either by inhibiting mRNA translation or inducing mRNA degradation (2). It is estimated that miRNAs regulate the expression of $>60 \%$ of human protein-encoding genes (3), and are involved in modulating multiple cellular pathways, including cell proliferation, differentiation and apoptosis (4).

Correspondence to: Dr Qunying Ma, Department of Gastroenterology, The Fifth Affiliated Hospital of Guangzhou Medical University, 621 Gangwan Road, Huangpu, Guangzhou, Guangdong 510700, P.R. China

E-mail: 125710484@qq.com

Key words: colorectal cancer, microRNA-106a, cell proliferation, apoptosis
miRNAs can serve as tumor suppressors or oncogenes, depending on their target mRNAs, and their expression can in turn be regulated by tumor suppressors (5) and oncogenes $(6,7)$. Aberrant expression of certain miRNAs has been observed in an array of human cancer types, and miRNAs are thought to serve important roles in tumorigenesis. Recently, a number of miRNAs have been identified as oncogenes or tumor suppressor genes in CRC (8-12).

miR-106a is expressed in cancer cells and in stool samples of patients with CRC with varying degrees (13-15). However, the molecular role that miR-106a serves in CRC remains debatable. Thus, in the present study, the biological consequence of overexpressing miR-106a in two distinct CRC cell lines was investigated.

\section{Materials and methods}

Cell lines and cultures. Human CRC cell lines HCT116 and SW620 were obtained from the Type Culture Collection of the Chinese Academy of Sciences (Shanghai, China). Cells were maintained in RPMI-1640 with 10\% fetal bovine serum (both from Invitrogen; Thermo Fisher Scientific, Inc., Waltham, MA, USA) and $1 \%$ antibiotics (100 U/ml penicillin and $100 \mu \mathrm{g} / \mathrm{ml}$ streptomycin sulfate) in a humidified atmosphere containing $5 \% \mathrm{CO}_{2}$ at $37^{\circ} \mathrm{C}$.

miRNA mimics and transfections. miR-106a mimics and nontarget control were purchased from Shanghai GenePharma Co., Ltd. (Shanghai, China). The sequences of these synthetic miRNAs were as follows: miR-106a mimic forward, 5'-AAA AGUGCUUACAGUGCAGGUAG-3' and reverse, 5'-ACCUGC ACUGUAAGCACUUUUUU-3'; nontarget control forward, 5'-UUCUCCGAACGUGUCACGUTT-3' and reverse, 5'-ACG UGACACGUUCGGAGAATT-3'. Cells were transfected with the miRNA (100 nM/l) using Lipofectamine ${ }^{\mathrm{TM}} 2000$ reagent (Invitrogen; Thermo Fisher Scientific, Inc.) following manufacturer's protocol.

Reverse transcription-quantitative polymerase chain reaction ( $R T-q P C R)$. Total RNA from cells was extracted using TRIzol (Invitrogen; Thermo Fisher Scientific, Inc.) according to manufacturer's protocol. First-strand cDNA synthesis was performed using the TaqMan MicroRNA 

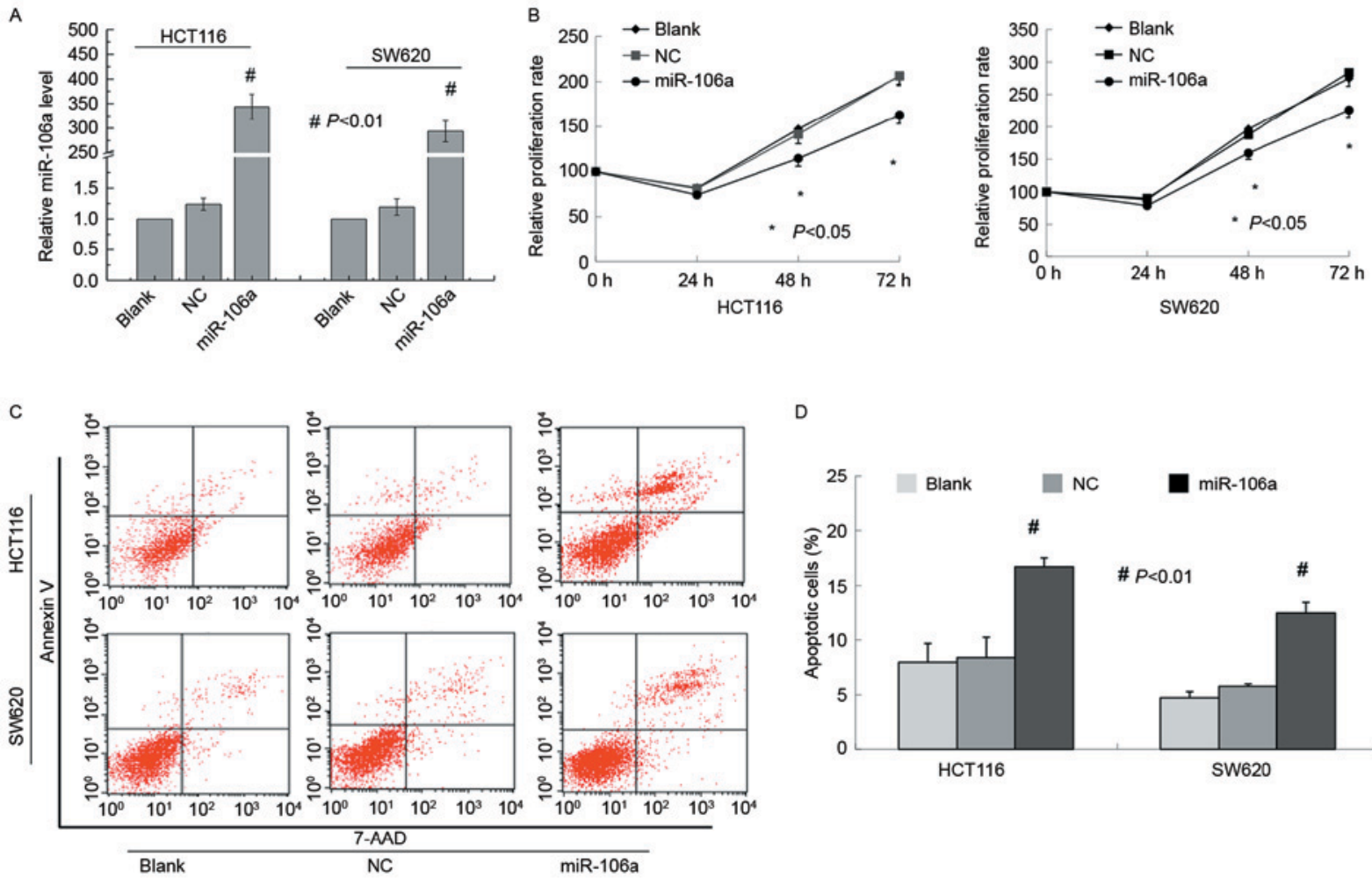

D
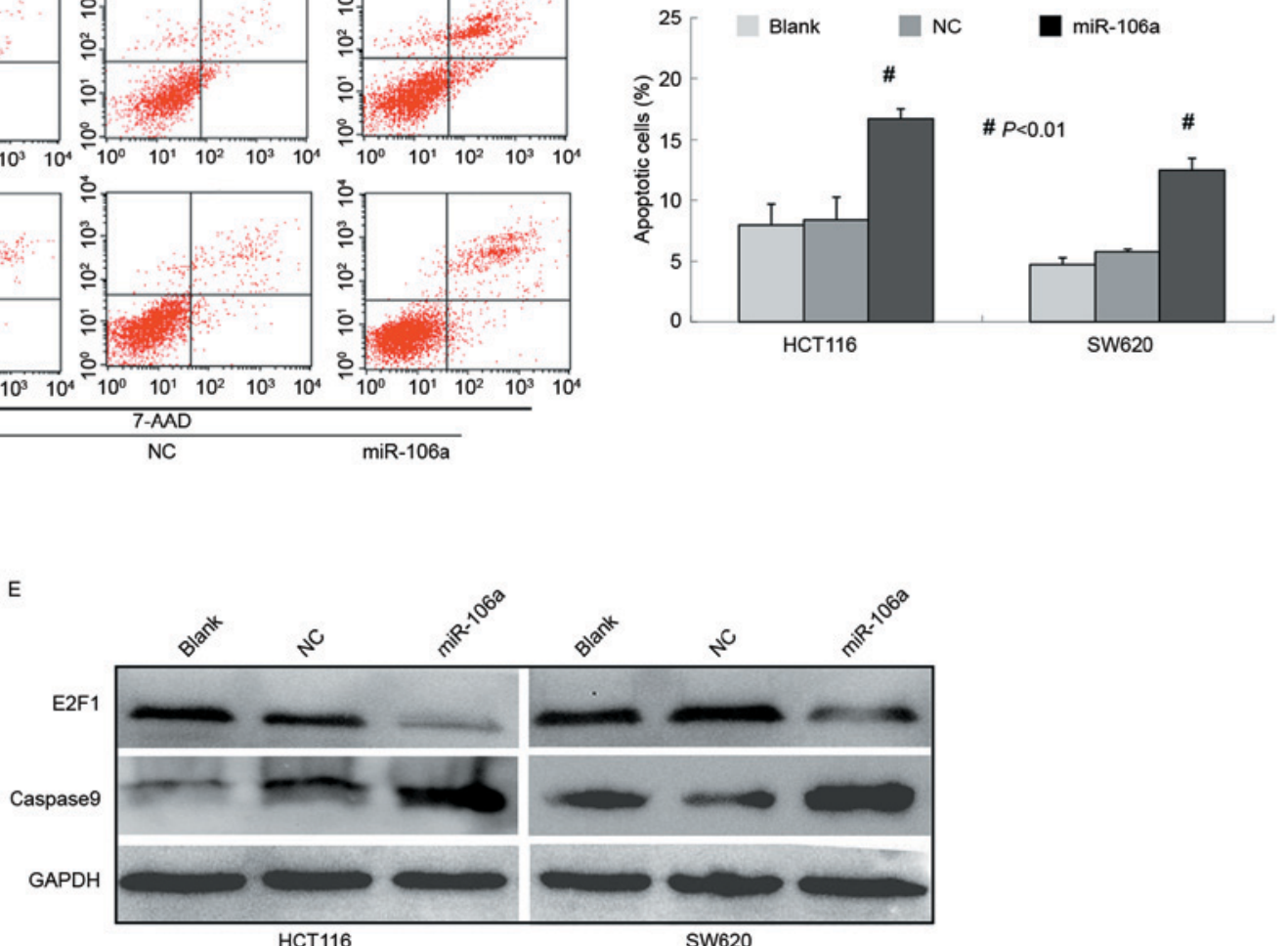

Figure 1. miR-106a inhibits the proliferation and induces the apoptosis of CRC cells. (A) Expression of miR-106a was determined using reverse transcription-quantitative polymerase chain reaction in HCT116 and SW620 cells $48 \mathrm{~h}$ after transfection with blank, NC, and miR-106a mimics. (B) Relative cell proliferation was determined using a cell counting kit-8 assay in HCT116 and SW620 cells transfected with blank, NC, and miR-106a mimics. (C) Apoptosis was analyzed with flow cytometry in HCT116 and SW620 cells transfected with blank, NC, and miR-106a mimics. (D) Graphical representation of the apoptosis of CRC cells using flow cytometry analysis as presented in C. (E) E2F1 and caspase-9 were detected using western blot assays in HCT116, and SW620 cells transfected with blank, NC, and miR-106a mimics. Data are expressed as the mean \pm standard deviation following three independent experiments. ${ }^{*} \mathrm{P}<0.05 ;{ }^{*} \mathrm{P}<0.01$. NC, nontarget control; miR, microRNA; CRC, colorectal cancer; E2F1, E2F transcription factor 1.

Reverse Transcription kit and miR-106a RT primers (Applied Biosystems; Thermo Fisher Scientific, Inc.). The temperature protocol of first-strand cDNA synthesis was: $16^{\circ} \mathrm{C}$ for $30 \mathrm{~min}$, $42^{\circ} \mathrm{C}$ for $30 \mathrm{~min}$ and $85^{\circ} \mathrm{C}$ for $5 \mathrm{~min}$. qPCR was performed using a miR-106a TaqMan MicroRNA Assay and TaqMan Universal Master Mix II on an ABI PRISM 7500 (Applied Biosystems; Thermo Fisher Scientific, Inc.). miR-106a primer sequence: GGAAAAGTGCTTACAGTGCAGGTA G. Thermocycler conditions used as follow: $95^{\circ} \mathrm{C}$ for $5 \mathrm{~min}$, followed by 40 cycles at $95^{\circ} \mathrm{C}$ for $30 \mathrm{sec}, 55^{\circ} \mathrm{C}$ for $40 \mathrm{sec}$ and $72^{\circ} \mathrm{C}$ for $30 \mathrm{sec}$. The expression of miR-106a was normalized to that of U6 (U6-forward primer: 5'-GTCGTATCC AGTGCAGGGTCCGAGGT-3'; U6-reverse primer: 5'-GCA CTGGATACGACAAAATATGGAAC-3'). Data analysis was performed using the $2^{-\triangle \Delta C q}$ method (16).
Cell proliferation assay. Cell proliferation was measured using a Cell Counting Kit-8 (CCK-8) assay (Beyotime Institute of Biotechnology, Haimen, China) according to manufacturer's protocol. Briefly, cells were plated in 96-well plates at a density of $0.5 \times 10^{4}$ cells/well. CCK- $8(10 \mu \mathrm{l})$ was added to each well prior to the colorimetric measurement. After $1 \mathrm{~h}$ incubation at $37^{\circ} \mathrm{C}$, the absorbance at $450 \mathrm{~nm}$ was measured using a microplate luminometer reader.

Cell apoptosis assay. Apoptosis assays were performed using an Annexin $\mathrm{V}$ apoptosis detection kit according to the manufacturer's protocol (BD Biosciences, San Jose, CA, USA). Briefly, CRC cells were collected after $72 \mathrm{~h}$ transfection, washed with PBS and resuspended in binding buffer containing $10 \mathrm{mM}$ HEPES (pH 7.4), $2.5 \mathrm{mM} \mathrm{CaCl}_{2}$, and 
$140 \mathrm{mM} \mathrm{NaCl}$. Annexin V-PE and 7-AAD were then added and flow cytometry analysis was performed after $15 \mathrm{~min}$ of incubation at room temperature.

Immunoblotting. Total protein was extracted using whole cell lysis buffer (Beyotime Institute of Biotechnology). Immunoblotting was performed as previously described (13). The following antibodies were used: 1, Anti-E2F transcription factor 1 (E2F1) (1:1,000; Cell Signaling Technology, Inc., Danvers, MA, USA); 2, anti-caspase-9 antibodies (1:3,000; Cell Signaling Technology, Inc.); 3, anti-GAPDH antibodies (1:10,000; Zhongshan Goldenbridge Biotechnology, Guangzhou, China). The membrane was washed with Tris-buffered saline with Tween-20 and incubated with a peroxidase-conjugated secondary antibody (1:1,000; Santa Cruz Biotechnology) for $1 \mathrm{~h}$. Protein bands were visualized using enhanced chemiluminesence substrates (EMD Millipore, Billerica, MA, USA).

Statistical analysis. Data are expressed as the mean \pm standard deviation and were analyzed using SPSS 13.0 software (SPSS Inc., Chicago, IL, USA). One-way analysis of variance was used for comparing multiple groups, followed with the Student-Newman-Keuls post hoc test. $\mathrm{P}<0.05$ was considered to indicate a statistically significant difference. All experiments were performed in biological triplicates.

\section{Results}

miR-106a overexpression inhibits the proliferation of colorectal cancer cells in vitro. The effect of miR-106a expression on the proliferation of CRC cells was examined first. HCT116 and SW620 cells were transiently transfected with nontarget control or miR-106a mimics. The RT-qPCR results demonstrated that cells transfected with miR-106a mimics exhibited a significantly higher level of miR-106a compared with cells transfected with a nontarget control miRNA or with mock transfection (Fig. 1A). In addition, cells overexpressing miR-106a mimics revealed a significant decrease in the cell proliferation rate 48 and $72 \mathrm{~h}$ after transfection (Fig. 1B).

miR-106a overexpression enhances apoptosis of colorectal cancer cells in vitro. Whether miR-106a overexpression induces apoptosis of CRC cells was examined next. Cells transfected with miR-106a or controls were stained with Annexin $\mathrm{V}$ and 7-AAD to measure cell apoptosis $72 \mathrm{~h}$ after transfection. miR-106a mimics caused significant increases in the percentage of apoptotic cells (HCT116: miR-106a, $16.69 \pm 0.82$ vs. nontarget control, $8.38 \pm 1.86 \%$; SW620: miR-106a, 12.44 \pm 0.971 vs. nontarget control, $5.77 \pm 0.21 \%$ ), while no significant difference was identified between the blank and nontarget control group (Fig. 1C and D).

miR-106a overexpression causes a marked change in the expression of E2F1 and cleaved caspase-9. Immunoblot analysis revealed that the protein level of E2F1 was decreased following miR-106a overexpression. Furthermore, caspase-9 cleavage was examined upon miR-106a overexpression and it was demonstrated that active caspase- 9 was significantly enhanced compared with control cells (Fig. 1E).

\section{Discussion}

miRNAs have been demonstrated to serve essential roles in carcinogenesis (17-21). Aberrant expression of certain miRNAs has been implicated in a variety of tumor properties, including growth, carcinogenesis, angiogenesis and apoptosis. The role of miR-106a serves in the malignant progression of tumors is complex and controversial. Numerous studies have revealed that miR-106a may serve as a tumor suppressor or an oncogene in different cancer types, which may be dependent on the cellular context $(22,23)$. For example, miR-106a exerts a tumor suppressive effect via suppressing proliferation and inducing apoptosis in human glioma cells by targeting E2F1, regardless of p53 status (22). In breasts cancer, miR-106a enhances cell proliferation and migration by negatively regulating zinc-finger and BTB domain containing 4 (23). However, the role of miR-106a in CRC carcinogenesis remains unclear.

The present work identified miR-106a as a tumor-suppressive miRNA in CRC cells in vitro. Overexpression of miR-106a induced apoptosis and decreased proliferation in CRC cells. The oncogene E2F1, target gene of miR-106a was decreased following miR-106a overexpression while apoptosis was elicited. Simultaneously, caspase-9 expression, an important caspase in the apoptotic pathway, was induced. Once active, caspase- 9 triggers a cascade of caspase activation events leading to apoptosis.

Collectively, the results of the current study demonstrated that miR-106a may serve as a tumor suppressor in CRC, potentially through regulating E2F1 and caspase-9 expression in cultured cancer cells. However, in vivo studies are warranted to validate these findings.

\section{Acknowledgements}

The authors would like to thank Dr Dennis Liang Fei of National Institutes of Health (Bethesda, USA) for providing editorial assistance.

\section{References}

1. Tenesa A and Dunlop MG: New insights into the aetiology of colorectal cancer from genome-wide association studies. Nat Rev Genet 10: 353-358, 2009.

2. Gu S, Jin L, Zhang F, Sarnow P and Kay MA: Biological basis for restriction of microRNA targets to the 3' untranslated region in mammalian mRNAs. Nat Struct Mol Biol 16: 144-150, 2009.

3. Friedman RC, Farh KK, Burge CB and Bartel DP: Most mammalian mRNAs are conserved targets of microRNAs. Genome Res 19: 92-105, 2009.

4. Esquela-Kerscher A and Slack FJ: Oncomirs-microRNAs with a role in cancer. Nat Rev Cancer 6: 259-269, 2006.

5. Xi Y, Shalgi R, Fodstad O, Pilpel Y and Ju J: Differentially regulated micro-RNAs and actively translated messenger RNA transcripts by tumor suppressor p53 in colon cancer. Clin Cancer Res 12: 2014-2024, 2006.

6. O'Donnell KA, Wentzel EA, Zeller KI, Dang CV and Mendell JT: c-Myc-regulated microRNAs modulate E2F1 expression. Nature 435: 839-843, 2005.

7. Woods K, Thomson JM and Hammond SM: Direct regulation of an oncogenic micro-RNA cluster by E2F transcription factors. J Biol Chem 282: 2130-2134, 2007.

8. He L, Thomson JM, Hemann MT, Hernando-Monge E, Mu D, Goodson S, Powers S, Cordon-Cardo C, Lowe SW, Hannon GJ and Hammond SM: A microRNA polycistron as a potential human oncogene. Nature 435: 828-833, 2005. 
9. Johnson SM, Grosshans H, Shingara J, Byrom M, Jarvis R, Cheng A, Labourier E, Reinert KL, Brown D and Slack FJ: RAS is regulated by the let-7 microRNA family. Cell 120: 635-647, 2005.

10. Lu J, Getz G, Miska EA, Alvarez-Saavedra E, Lamb J, Peck D Sweet-Cordero A, Ebert BL, Mak RH, Ferrando AA, et al: MicroRNA expression profiles classify human cancers. Nature 435: 834-838, 2005.

11. Roldo C, Missiaglia E, Hagan JP, Falconi M, Capelli P, Bersani S, Calin GA, Volinia S, Liu CG, Scarpa A and Croce CM: MicroRNA expression abnormalities in pancreatic endocrine and acinar tumors are associated with distinctive pathologic features and clinical behavior. J Clin Oncol 24: 4677-4684, 2006

12. Ventura A and Jacks T: MicroRNAs and cancer: Short RNAs go a long way. Cell 136: 586-591, 2009.

13. Schetter AJ, Leung SY, Sohn JJ, Zanetti KA, Bowman ED, Yanaihara N, Yuen ST, Chan TL, Kwong DL, Au GK, et al: MicroRNA expression profiles associated with prognosis and therapeutic outcome in colon adenocarcinoma. JAMA 299: 425-436, 2008

14. Díaz R, Silva J, García JM, Lorenzo Y, García V, Peña C, Rodríguez R, Muñoz C, García F, Bonilla F and Domínguez G: Deregulated expression of miR-106a predicts survival in human colon cancer patients. Genes Chromosomes Cancer 47: 794-802, 2008.

15. Link A, Balaguer F, Shen Y, Nagasaka T, Lozano JJ, Boland CR and Goel A: Fecal MicroRNAs as novel biomarkers for colon cancer screening. Cancer Epidemiol Biomarkers Prev 19: $1766-1774,2010$

16. Livak KJ and Schmittgen TD: Analysis of relative gene expression data using real-time quantitative PCR and the 2(-Delta Delta C(T)) method. Methods 25: 402-408, 2001.
17. Calin GA,Liu CG, Sevignani C, Ferracin M, Felli N, Dumitru CD, Shimizu M, Cimmino A, Zupo S, Dono M, et al: MicroRNA profiling reveals distinct signatures in B cell chronic lymphocytic leukemias. Proc Natl Acad Sci USA 101: 11755-11760, 2004.

18. Calin GA, Sevignani C, Dumitru CD, Hyslop T, Noch E, Yendamuri S, Shimizu M, Rattan S, Bullrich F, Negrini M and Croce CM: Human microRNA genes are frequently located at fragile sites and genomic regions involved in cancers. Proc Natl Acad Sci USA 101: 2999-3004, 2004.

19. Jovanovic M and Hengartner MO: miRNAs and apoptosis: RNAs to die for. Oncogene 25: 6176-6187, 2006

20. Kent OA and Mendell JT: A small piece in the cancer puzzle: microRNAs as tumor suppressors and oncogenes. Oncogene 25: 6188-6196, 2006.

21. Volinia S, Calin GA, Liu CG, Ambs S, Cimmino A, Petrocca F, Visone R, Iorio M, Roldo C, Ferracin M, et al: A microRNA expression signature of human solid tumors defines cancer gene targets. Proc Natl Acad Sci USA 103: 2257-2261, 2006.

22. Yang G, Zhang R, Chen X, Mu Y, Ai J, Shi C, Liu Y, Shi C, Sun L, Rainov NG, et al: MiR-106a inhibits glioma cell growth by targeting E2F1 independent of p53 status. J Mol Med (Berl) 89: 1037-1050, 2011.

23. Kim K, Chadalapaka G, Lee SO, Yamada D, Sastre-Garau X, Defossez PA, Park YY, Lee JS and Safe S: Identification of oncogenic microRNA-17-92/ZBTB4/specificity protein axis in breast cancer. Oncogene 31: 1034-1044, 2012.

This work is licensed under a Creative Commons Attribution-NonCommercial-NoDerivatives 4.0 International (CC BY-NC-ND 4.0) License. 